\title{
Economic Inequality in Sumatra 2010-2020
}

\author{
Arivina Ratih Taher ${ }^{1}$, Ukhti Ciptawaty ${ }^{2}$, Emi Maimunah ${ }^{3}$ \\ \{arivinaratih@gmail.com ${ }^{1}$, ciptawaty@gmail.com ${ }^{2}$,emi_syam@yahoo.com ${ }^{3}$ \} \\ Universitas Lampung, Indonesia ${ }^{1}$, Universitas Lampung, Indonesia ${ }^{2}$, Universitas Lampung, \\ Indonesia $^{3}$
}

\begin{abstract}
Economic inequality is a phenomenon that will always exist because the economic growth of each region is inequal. Sumatra is the choice of research area because it has ten provinces with varying regional conditions and economic activities. The majority of provinces have a large role in the agricultural sector, but some have industrial, and some have economically valuable mining materials. The research has conducted in the period 2010-2020 with secondary data obtained from the Statistic Indonesia. Period 2010 to 2019 uses annual data, while 2020 is quarterly. This study aims to capture the dynamics of regional inequality by Williamson Index, and descriptive analysis used to explain the dynamics of inequality in 2019 and 2020 when Covid-19 began to infect Indonesia. The results of the calculation show that regional inequality in Sumatra is decreasing even though Covid-19 is hitting it. The decrease happens because all economic activities in the ten observed provinces have slowed down. The decline in sector activity in 2020 mainly occurred in the transportation and warehousing sectors as well as the provision of food and drink accommodation sectors. The condition is related to limiting population mobilization as an effort to prevent the spread of the virus. The limitation of this research lies in the lack of detailed provincial data available for 2020 .
\end{abstract}

Keywords: Covid-19, Gross Regional Domestic Product, Inequality, Sumatra, Williamson Index

\section{Introduction}

Inequality is a never-ending phenomenon in regional development. This condition will always occur because each region develops and grows at different rates [1]. The discussion of inequality can never be separate from the Kuznets Hypothesis [2] regarding the Inverted U curve, which is still an interesting research topic to prove. Williamson (1965) took a different approach from Kuznets (1955) to analyze inequality, but the results found were successful in proving Kuznets' hypothesis about the Inverted U curve [3]. The approach used by Williamson (1965) is now better known as the Williamson Index

Sumatra is a draw attention research object for several reasons. Sumatra has always been the second contributor to Indonesia's income after Java. Sumatra has provinces with diverse economic activities that can be seen at the contribution of the economics sector to the 2019 Gross Regional Domestic Product (GRDP). Riau Islands (37.57\%), Riau (30.91\%), and Lampung $(19.15 \%)$ are the top three provinces with the highest processing Industry activity. Jambi (24.10\%), South Sumatra (22.62\%), and Riau (17.27\%) are the top three for Mining and Processing activities. Aceh (27.77\%), Lampung (27.76), and Riau (26.16\%) are the top three 
for Agricultural, Forestry, and Fishery activities. Apart from economic activity, the Riau Islands and Lampung benefit from their geographic location near the centers of growth, namely Singapore and Java. Some of these things make each province in Sumatra have its style of development, allowing the creation of gaps, especially in the economic sector.

In addition to the things already mentioned, economic inequality is facing new challenges, namely the Covid-19 pandemic, which has plagued all regions, including Sumatra. Efforts made to inhibit the spread of the virus resulted in a decrease in economic activity. Therefore, this paper aims to capture at the dynamics of regional economic inequality in Sumatra ten years before the pandemic (2010-2019) and when the pandemic occurred (2020 $1^{\text {st }}$ and $2^{\text {nd }}$ quarter). Hopefully, this paper can provide a short-term picture of the economic slowdown and inequality between regions in Sumatra.

\section{Method}

Inequality has become an issue that will not resolve because inequality will always exist and have an impact on many things. Kuznets' hypothesis is a topic that becomes a lot of reference when talking about inequality. Inequality is measure by the Gini index and hypothesized as an inverted U curve. Many researchers tried to prove the truth of this hypothesis, along with looking for causes, impacts, and solutions to overcome inequality. High inequality will affect economic growth in many ways, increasing social problems, political instability, and decreasing aggregate demand [4]. In line with this, it stated that inequality could affect the growth of macroeconomic variables and reduce opportunities.0 to obtain education [5]. on the other hand, low inequality provides better opportunities for access to health, a comfortable environment, and low crime [6].

The research data come from Statistics Indonesia (BPS) that downloaded via https://bps.go.id. The income of ten provinces in Sumatra from 2010 to 2019 is the Gross Regional Domestic Product (GRDP) of the industrial origin sector at constant 2010 prices, the unit used is billion Rupiah. For per capita income, data is taken from the GRDP per capita at 2010 constants prices in units of million Rupiah. The use of secondary data from Statistics Indonesia faces some limitations. GRDP per capita data and total population are not yet available for 2020, so the value is calculated by dividing the 2010 constant price GRDP value by the 2019 population.

Regional inequality as the main topic of research is calculated using the Williamson Index [3] as follows.

$$
V_{w}=\frac{\sqrt{\sum_{i}\left(y_{i}-\bar{y}\right)^{2} \frac{f_{i}}{n}}}{\bar{y}}
$$

\footnotetext{
$V_{w} \quad:$ Williamson Index

$y_{i} \quad$ : GRDP per capita for province $\mathrm{i}$

$\bar{y} \quad$ : Average of GRDP per capita for Sumatra
} 
$f_{i} \quad$ : Population of province $\mathrm{i}$

$n \quad$ : Total Population in Sumatra

\section{Result and Discussion}

Regional economic disparities between provinces in Sumatra in the last ten years can be seen in Table 1. Specifically for 2020, the data obtained from BPS is still quarterly data.

Table 1. Willimason Index for Sumatra in 2010-2020

(*) Temporary. Data are taken from Statistic Indonesia https://bps.go.id/ accessed in August 2020. 'Gross Regional Domestic Product 2010-2019'updated on 15/08/2019, 'Per Capita Gross Regional Domestic Product by Province 2010-2019'updated on 15/08/2019. 'GRDP at Constant Market Prices by Expenditure $(2010=100), 2010-2020$ ' updated on 14/07/2020.

\begin{tabular}{cc}
\hline YEAR & WILLIAMSON INDEX \\
\hline 2010 & 0,498 \\
2011 & 0,491 \\
2012 & 0,478 \\
2013 & 0,462 \\
2014 & 0,451 \\
2015 & 0,434 \\
2016 & 0,420 \\
2017 & 0,404 \\
2018 & 0,390 \\
2019 & 0,379 \\
$20201^{\text {ST }}$ QUARTER* & 0,376 \\
$20202^{\text {ND }}$ QUARTER* & 0,363 \\
\hline
\end{tabular}

The condition of inequality between provinces until 2020 shows a value that continues to decline, although it is not very significant. The surprising thing happened in the first and second quarters of 2020, inequality between provinces still showed a decreasing value despite the pandemic. Some of the details regarding this matter can be seen as follows.

Table 2. Growth of GRDP per capita in Ten Provinces in Sumatra, 2011-2020 (Percent)

(*) represent Provinces with a per capita GRDP value above the Sumatra average. 2020 is the GRDP per capita growth of $1^{\text {st }}$ to $2^{\text {nd }}$ quarter. Data taken from Statistic Indonesia https://bps.go.id/ accessed in August 2020. 'Gross Regional Domestic Product 2010-2019'updated on 15/08/2019, 'Per Capita Gross Regional Domestic Product by Province 2010-2019'updated on 15/08/2019. 'GRDP at Constant Market Prices by Expenditure (2010=100), 2010-2020' updated on 14/07/2020.

\begin{tabular}{ccccccccccc}
\hline Provinces & $\mathbf{2 0 2 0}$ & $\mathbf{2 0 1 9}$ & $\mathbf{2 0 1 8}$ & $\mathbf{2 0 1 7}$ & $\mathbf{2 0 1 6}$ & $\mathbf{2 0 1 5}$ & $\mathbf{2 0 1 4}$ & $\mathbf{2 0 1 3}$ & $\mathbf{2 0 1 2}$ & $\mathbf{2 0 1 1}$ \\
\hline Aceh & $-1,28$ & 2,40 & 2,79 & 2,31 & 1,38 & $-2,61$ & $-0,43$ & 0,56 & 1,74 & 1,13
\end{tabular}




\begin{tabular}{|c|c|c|c|c|c|c|c|c|c|c|}
\hline Provinces & 2020 & 2019 & 2018 & 2017 & 2016 & 2015 & 2014 & 2013 & 2012 & 2011 \\
\hline $\begin{array}{l}\text { North } \\
\text { Sumatra }\end{array}$ & $-4,75$ & 4,16 & 4,06 & 3,95 & 3,94 & 3,81 & 3,88 & 4,65 & 4,96 & 5,11 \\
\hline $\begin{array}{l}\text { West } \\
\text { Sumatra }\end{array}$ & $-5,50$ & 3,91 & 3,98 & 4,07 & 4,00 & 4,23 & 4,53 & 4,69 & 4,88 & 4,88 \\
\hline Riau* & $-4,49$ & 0,53 & 0,01 & 0,24 & $-0,28$ & $-2,24$ & 0,13 & $-0,14$ & 1,06 & 2,78 \\
\hline Jambi & $-1,41$ & 2,84 & 3,12 & 2,93 & 2,65 & 2,44 & 5,49 & 4,92 & 5,06 & 5,82 \\
\hline $\begin{array}{l}\text { South } \\
\text { Sumatra }\end{array}$ & $-2,30$ & 4,46 & 4,73 & 4,16 & 3,65 & 2,98 & 3,30 & 3,78 & 5,23 & 4,73 \\
\hline Bengkulu & $-2,98$ & 3,46 & 3,43 & 3,38 & 3,63 & 3,44 & 3,74 & 4,28 & 4,98 & 4,97 \\
\hline Lampung & $-0,56$ & 4,30 & 4,23 & 4,09 & 4,01 & 3,95 & 3,85 & 4,48 & 5,09 & 5,16 \\
\hline $\begin{array}{l}\text { Kep.Bangka } \\
\text { Belitung }\end{array}$ & $-2,38$ & 1,32 & 2,39 & 2,35 & 1,95 & 1,89 & 2,43 & 2,92 & 3,18 & 4,52 \\
\hline Kep.Riau* & $-7,55$ & 2,35 & 1,94 & $-0,69$ & 2,12 & 3,03 & 3,49 & 3,97 & 4,27 & 3,53 \\
\hline
\end{tabular}

During the observation period, the provinces of Riau and Kepulauan Riau were areas with GRDP values per capita above the Sumatra average. However, the GRDP per capita growth says differently, Riau and Kepulauan Riau are regions with slow growth and are often have negative when other provinces grow positively. The negative value of Riau and Kepulauan Riau before 2020 occurred due to a decline in the Mining and Excavation sector, and in 2020 because the majority of all sectors experienced a decline [7]. This kind of phenomenon (before 2020) does not only happen in Sumatra but also in other parts of the world, which are usually known as the curse of endowment resources areas with abundant natural resources experience a slowdown in economic growth and may even become poor.

The region is declared to have suffered a curse because it has a wealth of natural or mineral resources but experiences slow economic growth. After being studied, the researchers found that these areas also have high poverty rates, low quality of human resources, high corruption, and poorly organized government. Some researchers have tried to study this curse, and it turns out that these conditions are not due to the existence of abundant natural resources alone but from a poorly management system [8]-[10]. They also highlighted the government's weak role in creating good governance. According to these findings, economic growth has not formed from just one variable.

GRDP data for industrial origin taken from https://bps.go.id/ in August 2020, provides additional information that the Transportation and Warehousing sector, as well as the Provision of Food and Beverage Accommodation, has decreased in all provinces in Sumatra by 2020. It is happening because population mobility between regions is limited as an effort to reduce the spread of Covid-19. The tourism, shipping, and land transportation industries are the most affected economic activities. As a result, the sectors related to this industry also experienced a decline.

The Covid-19 pandemic is an extraordinary event that has an impact on many lines of human life at the same time, and it is also harming the economy. A reduction in economic inequality between regions is something to be expected but treated very carefully. 
Table 3. GRDP on 2010 Constant Prices for 2019 and 2020

Data taken from Statistic Indonesia https://bps.go.id/ accessed in August 2020. ‘Gross Regional Domestic Product 2010-2019'updated on 15/08/2019, 'Per Capita Gross Regional Domestic Product by Province 2010-2019'updated on 15/08/2019. 'GRDP at Constant Market Prices by Expenditure (2010=100), 2010-2020' updated on 14/07/2020.

\begin{tabular}{|c|c|c|c|c|c|c|}
\hline \multirow{2}{*}{ Province } & \multicolumn{3}{|c|}{2019} & \multicolumn{3}{|c|}{2020} \\
\hline & $\mathbf{1}^{\text {st }}$ Quarter & $2^{\text {nd }}$ Quarter & Growth & $1^{\text {st }}$ Quarter & $2^{\text {nd }}$ Quarter & Growth \\
\hline Aceh & $31.631 .504,14$ & $32.815 .953,83$ & 3,74 & $32.635 .561,14$ & $32.217 .428,60$ & $-1,28$ \\
\hline North Sumatra & $130.644 .380,01$ & $133.391 .429,90$ & 2,10 & $136.722 .684,23$ & $130.232 .504,10$ & $-4,75$ \\
\hline West Sumatra & $41.451 .401,18$ & $42.801 .515,33$ & 3,26 & $43.067 .320,39$ & $40.698 .281,36$ & $-5,50$ \\
\hline Riau* & $120.394 .789,68$ & $121.463 .550,82$ & 0,89 & $123.086 .125,50$ & $117.555 .193,86$ & $-4,49$ \\
\hline Jambi & $36.263 .418,23$ & $37.055 .644,66$ & 2,18 & $36.939 .869,34$ & $36.419 .108,37$ & $-1,41$ \\
\hline South Sumatra & $75.665 .370,15$ & $78.680 .614,43$ & 3,98 & 79.437.077,03 & $77.606 .577,20$ & $-2,30$ \\
\hline Bengkulu & $11.373 .418,44$ & $11.508 .228,11$ & 1,19 & $11.805 .750,57$ & $11.453 .391,89$ & $-2,98$ \\
\hline Lampung & $59.359 .020,22$ & $62.279 .332,99$ & 4,92 & $60.394 .575,54$ & $60.056 .210,43$ & $-0,56$ \\
\hline Kep.Bangka & & & & & & \\
\hline Belitung & $12.986 .597,19$ & $13.521 .362,14$ & 4,12 & $13.161 .456,98$ & $12.847 .635,49$ & $-2,38$ \\
\hline Kep.Riau* & $44.285 .333,10$ & $44.766 .783,34$ & 1,09 & $45.199 .627,84$ & $41.785 .612,28$ & $-7,55$ \\
\hline
\end{tabular}


The quarterly GRDP values for 2019 and 2020 indicate things that need attention. The GRDP value of all provinces in the second period of 2020 has decreased compared to the same quarter in 2019. The highest decrease came from the service sector that was affected by government policies to prevent the spread of the virus. A decreased in the GRDP value can reduce the value of the GDRP per capita, assuming a permanent population. If the population increases, the value of the GDRP per capita will decrease even further. The decreasing economic inequality as a result of this is not what any region wants.

\section{Conclusion}

Inequality in Sumatra, measured by the Williamson Index, shows a decreasing value, even in the period of the spread of Covid-19. The cause of this thought to be because economic activities in ten provinces fell simultaneously, with varying rates of decline in various sectors. In addition, the decline in economic inequality is due to the slow growth of GRDP per capita in Riau and Riau Islands.

The analysis in 2020 is still very temporary because the data is not yet available in detail for some areas, so it opens up opportunities for research with more detailed data. Besides, the impact of Covid-19 on the economy will still be an attractive topic of discussion for the next few years. The upcoming research needs a more comprehensive study related to other socioeconomic problems such as consumption patterns, purchasing power, poverty, the quality of human resources, and connectivity between regions, which is like the horn of a dilemma. It can be a factor that helps economic growth, but it can also have a negative impact during the pandemic

Acknowledgement. Thank you to the Faculty of Economics and Business Universitas Lampung for the supports that have been given so the author can attend the third ICEBE conference in 2020 .

\section{References}

[1] N. Kaldor, "The Case for Regional Policies," Scott. J. Polit. Econ., vol. 60, no. 5, pp. 481-491, 2013, doi: 10.1111/sjpe.12020.

[2] S. Kuznets, "Economis Growth and Income Inequality," Am. Econ. Rev., vol. 45, no. 1, pp. 1-28, 1955, doi: 10.2307/1811581.

[3] Jeffrey G . Williamson, "Regional Inequality and the Process of National Development: A Description of the Patterns Source Part 2 ( Jul ., 1965 ),” Econ. Dev. Cult. Change, vol. 13, no. 4, pp. 1-84, 2016.

[4] D. Castells-Quintana and V. Royuela, "Tracking positive and negative effects of inequality on long-run growth," Empir. Econ., vol. 53, no. 4, pp. 1349-1378, 2017, doi: 10.1007/s00181-016-1197-y.

[5] T. A. DiPrete, "The Impact of Inequality on Intergenerational Mobility," Annu. Rev. Sociol., vol. 46, no. 1, pp. 379-398, 2020, doi: 10.1146/annurev-soc-121919-054814.

[6] R. G. Wilkinson, “The Impact of Inequality,” Soc. Res. (New. York)., vol. 73, no. 2, pp. 711-732, 2006, doi: 10.2307/40971843. 
[7] S. L. BPS, Produk Domestik Regional Bruto Provinsi-Provinsi di Indonesia Menurut Lapangan Usaha 2015-2019. Jakarta: BPS RI, 2020.

[8] P. Jones Luong, E. Weinthal, P. Jones Luong, and E. Weinthal, "The Myth of the Resource Curse," Oil Is Not a Curse, vol. 47, no. 2, pp. 322-336, 2012, doi: 10.1017/cbo9780511779435.010.

[9] R. F. Mikesell, "Explaining the resource curse, with special reference to mineralexporting countries," Resour. Policy, vol. 23, no. 4, pp. 191-199, 1997, doi: 10.1016/s0301-4207(97)00036-6.

[10] J. J. Quinn and R. T. Conway, "The Mineral Resource Curse in Africa : What Role Does Majority State Ownership Play? The Mineral Resource Curse in Africa : What Role Does Majority State Ownership Play? by Associate Professor of Political Science Truman State University and," no. July 2014, 2010. 